\title{
Trophic relationships between sperm whales and jumbo squid using stable isotopes of $\mathbf{C}$ and $\mathbf{N}$
}

\author{
R. I. Ruiz-Cooley ${ }^{1, *}$, D. Gendron ${ }^{1}$, S. Aguíñiga ${ }^{1}$, S. Mesnick ${ }^{2,3}$, J. D. Carriquiry ${ }^{4}$ \\ ${ }^{1}$ Centro Interdisciplinario de Ciencias Marinas, Instituto Politécnico Nacional, Apartado Postal 592, CP 23000 La Paz, \\ Baja California Sur, Mexico \\ ${ }^{2}$ Southwest Fisheries Science Center, NOAA-Fisheries, 8604 La Jolla Shores Drive, La Jolla, California 92037, USA \\ ${ }^{3}$ Marine Biodiversity and Conservation, Scripps Institution of Oceanography, University of California San Diego, La Jolla, \\ California 92093, USA \\ ${ }^{4}$ Instittuto de Investigaciones Oceanologicas, Universidad Autonoma de Baja California, Apartado Postal 453,
} CP 22800 Ensenada, Baja California, Mexico

\begin{abstract}
The trophic position and the predator-prey relationship between the sperm whale Physeter macrocephalus and the jumbo squid Dosidicus gigas were examined by measuring stable isotope ratios of carbon and nitrogen. Skin samples of sperm whales and muscle samples of small and large jumbo squid were collected between 1996 and 1999 in the Gulf of California. Gender determination through molecular analysis and field identification of size were used to identify adult male, female and immature male sperm whales. The stable isotope ratios of $\mathrm{C}$ and $\mathrm{N}$ of females and immature males were significantly different from those of adult male sperm whales; however, between females and immature males they did not differ significantly. The $\delta^{13} \mathrm{C}$ and $\delta^{15} \mathrm{~N}$ values of females and immature males were higher than large jumbo squid by $1.1 \%$ and $2.7 \%$ respectively, suggesting a predator-prey relationship between them. A low isotopic interannual variation among the years 1997 to 1999 was observed in the isotopic signature of females and males. Adult males exhibited a lower isotopic signature than females and immature males, and did not show a trophic relationship with $D$. gigas. We hypothesized that the stable isotopic signature of mature males reflected their diet from an earlier high-latitude feeding ground. This study shows that stable isotope analysis of sloughed skin samples from free-ranging sperm whales can be an alternative method to stomach content and fecal analyses for evaluating trophic relationships.
\end{abstract}

KEY WORDS: Trophic relationships - Trophic position $\cdot$ Stable isotopes $\cdot$ Sperm whales $\cdot$ Jumbo squid $\cdot$ Cetaceans

Resale or republication not permitted without written consent of the publisher

\section{INTRODUCTION}

Top predators are key indicators of the productivity level and state of ecosystems. Knowledge of their trophic role, including the degree of interannual variation, is essential for understanding their ecology. The sperm whale Physeter macrocephalus is one of the top predators in the mesopelagic ocean (Rice 1989). It preys mainly on mesopelagic and bathypelagic cephalopods (Okutani \& Nemoto 1964, Clarke 1980, Kawakami 1980). In general, the diet composition of sperm whales may include a large variety of food items, which may reflect the abundance and diversity of the potential prey inhabiting a region (Berzin 1971, Kawakami 1980). However, in some oceanic areas sperm whales appear to feed primarily on a specific prey. In the Humboldt Current, the jumbo squid Dosidicus gigas (Ommastrephidae) has a high frequency of occurrence in the diet of sperm whales (Clarke et al. 1988, Clarke \& Paliza 2000). The jumbo squid is endemic to the eastern Pacific (Nigmatullin et al. 2001), and it is an important fishery resource in the Humboldt Current and in the Gulf of California, Mexico. Because of the co-existence of sperm whales and jumbo squid in the Gulf of California, a potential predator-prey relationship has been suggested (Vidal 
et al. 1993). However, the diet composition of sperm whales in the Gulf of California remains largely unknown.

Studying and understanding the feeding ecology of sperm whales is difficult, due to the sampling limitations associated with both sperm whales and squid. Analysis of prey remains obtained from the stomachs of hunted and stranded sperm whales has been the main method for investigating diet composition and obtaining data about the distribution, relative abundance and biology of many deepwater cephalopod taxa (e.g. Clarke 1983, 1986). Fecal analysis has also proven to be useful in investigating the diet of freeranging sperm whales (Smith \& Whitehead 2000). Although both stomach contents and fecal analyses have provided valuable information about the food types consumed by sperm whales, some important methodological limitations make the interpretation of the results debatable (see Clarke 1980, 1985, Clarke et al. 1988, Pascoe et al. 1990, Smith \& Whitehead 2000, 2001, Clarke \& Paliza 2001).

Over the past 2 decades, the analysis of carbon and nitrogen isotope ratios $\left(\delta^{13} \mathrm{C}\right.$ and $\left.\delta^{15} \mathrm{~N}\right)$ has been a tool in ecological research. The natural abundances of stable isotopes in animal tissues reflect the average isotopic composition of the animal's assimilated diet (DeNiro \& Epstein 1978, 1981, Rau et al. 1983, 1992, Minawaga \& Wada 1984, Wada et al. 1987, Fry 1988, Hobson \& Welch 1992, Hobson et al. 1994). Thus, the technique has been used to understand the trophic ecology of marine mammals. However, most tissue samples have been obtained from hunted, stranded and captive marine mammals, which limits our ability to infer the feeding habits of free-ranging individuals. Recently, the measurement of stable isotope ratios from skin samples obtained by directed biopsy of cetaceans at sea has provided an alternative means of investigating the dietary habits of free-ranging animals (e.g. Todd et al. 1997, Gendron et al. 2001, Hooker et al. 2001). The nitrogen isotopic composition of marine fauna is an indicator of trophic position (Fry 1988), whereas carbon isotopic composition reflects the sources of primary production (Rau et al. 1992). In this study, a combination of $\delta^{13} \mathrm{C}$ and $\delta^{15} \mathrm{~N}$ was used to identify the relative trophic position of sperm whales.

We quantified the stable isotopes of $\mathrm{C}$ and $\mathrm{N}$ in skin samples of free-ranging sperm whales from the Gulf of California in order to evaluate potential differences in trophic position as a function of sex and level of maturation. In some oceanic areas, it has been shown that adult male sperm whales have a tendency to feed on larger prey than juveniles and females (e.g. Clarke 1980, Clarke et al. 1988). We tested the hypothesis that mature male sperm whales have higher stable isotope signatures, indicative of feeding at a higher trophic position, compared with females and juvenile males. Another objective of this study was to find out if the jumbo squid Dosidicus gigas is preyed upon by sperm whales in the Gulf of California.

\section{MATERIALS AND METHODS}

Tissue sampling. Sloughed skin samples were collected from free-ranging sperm whales in $1996(\mathrm{n}=1)$, $1997(\mathrm{n}=2), 1998(\mathrm{n}=9)$ and $1999(\mathrm{n}=22)$ in the Gulf of California. Sighting data, GPS position and the number of individuals in each cluster, following Whitehead \& Arnbom (1987), were recorded. Tail-fluke photographs (black and white, ISO 400) were taken for individual identification in order to avoid sampling the same animal more than once. However, it was not possible to photograph all individuals. Sloughed skin samples of sperm whales were collected in the slick of the sperm whale during surfacing period using a small dip net $(30 \times 20 \mathrm{~cm} ; 1 \mathrm{~mm}$ mesh). Biopsy samples $(\mathrm{n}=7)$ from free-ranging sperm whales were available from a collection made by the Regional Fishery Center (Centro Regional de Investigación Pesquera: CRIP), Mexico, in the Gulf of California in August of 1997. Skin samples $(n=2)$ collected from a stranded adult male sperm whale in January 1993 and a stranded sperm whale of unidentified sex in November 1999 were also included in the study (Fig. 1).

Large jumbo squid were collected in 1996 and 1997 in the Gulf of California $\left(27^{\circ} 17^{\prime} \mathrm{N}, 112^{\circ} 09^{\prime}\right.$ to $\left.113^{\circ} 09^{\prime} \mathrm{W}\right)$. Small jumbo squid were collected in March 1999 (2512' N, 11049' W). Mantle length was measured on every squid collected. A small portion of muscle tissue from the oral area was removed for isotopic analyses and stored frozen at $-4^{\circ} \mathrm{C}$.

Genetic analyses. All skin samples of sperm whales were stored in an aqueous solution of $20 \%(\mathrm{v} / \mathrm{v})$ dimethyl sulfoxide (DMSO) saturated with sodium chloride (Amos \& Hoelzel 1991). Skin samples of sperm whales were used to determine gender mainly through amplification of the SRY region (Richard et al. 1994). Variation in the regions of zinc fingers of the $\mathrm{X}$ and $\mathrm{Y}$ chromosomes (Bérubé \& Palsboll 1996) and the restriction method based on the region of zinc finger (Rosenberg \& Mesnick 2001) were also used to confirm the sex of each individual. Sperm whales are strongly sexually dimorphic (Rice 1989) and adult males can be easily identified in the field. We identified 6 free-ranging adult males, all with a posteriori DNA confirmation. The remaining 35 free-ranging individuals were identified genetically. All individuals were categorized as follows: (1) adult males, (2) females (immature and/or adult individuals) and (3) immature males. No skin samples were obtained from calves. Gender 


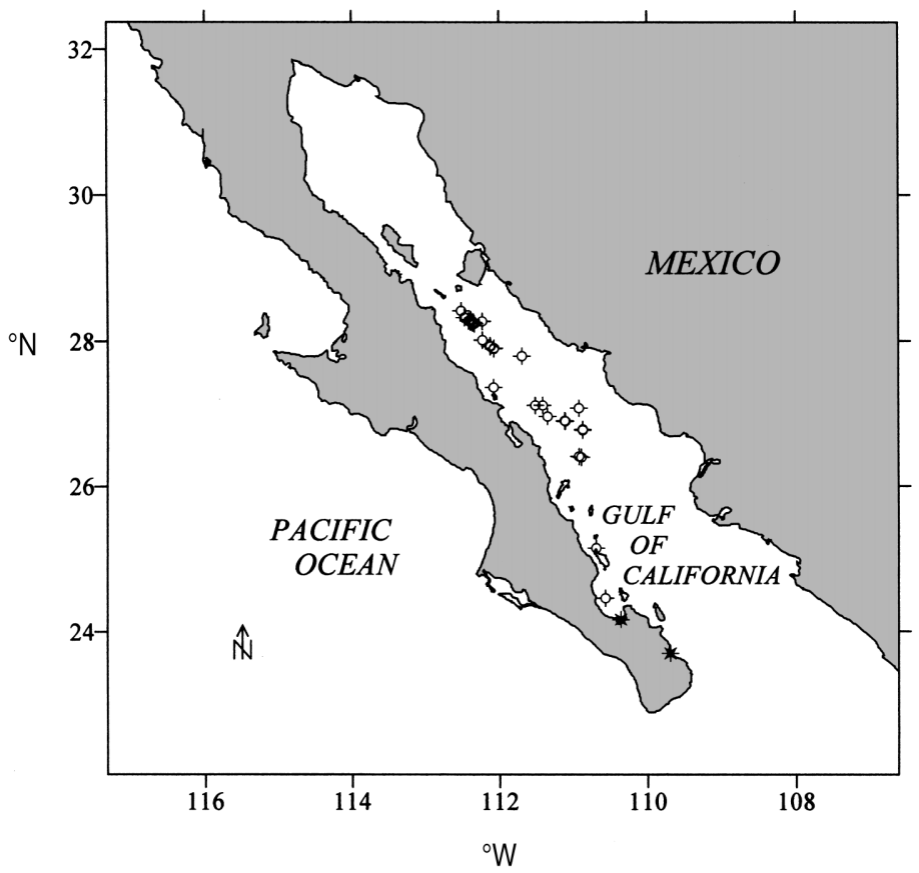

Fig. 1. Physeter macrocephlaus. Skin sample location of freeranging (- - ) and stranded (*) individuals in the Gulf of California, Mexico

determination failed for 11 skin samples; the individuals from which they were obtained were, therefore, classified as non-differentiated sperm whales. This latter group consisted of females (both adult and immature) and/or immature males, but did not include adult males. The sperm whale stranded in November was included in the latter group.

Stable isotope analysis. Lipids tend to be depleted in ${ }^{13} \mathrm{C}$ (DeNiro \& Epstein 1977, Tieszen et al. 1983) relative to whole-tissue samples, thus low $\delta^{13} \mathrm{C}$ values would be expected for samples with high lipid content. Therefore, our tissue samples were freeze-dried and the lipids were removed following sonication using a mixture of chloroform and methanol (1:1) (modified technique from Bligh \& Dyer 1959). As DMSO does not appear to alter the $\delta^{13} \mathrm{C}$ values in lipid-extracted skin samples of humpback whales, and sonication is an effective method for DMSO removal (Todd et al. 1997), only minor effects from DMSO are expected in the skin samples of sperm whales. All squid and sperm whale samples were subsequently dried and ground into a homogeneous fine powder. Duplicate skin samples were analyzed only for sperm whales, except for the stranded adult male. Analyses were carried out using an Optima isotope ratio mass spectrometer interfaced in continuous flow to a Carlo Erba Elemental Analyzer (NA-1500 CNS). The $\delta^{13} \mathrm{C}, \delta^{15} \mathrm{~N}$ and $\mathrm{C}: \mathrm{N}$ ratio were obtained for each sample. Isotope ratios are expressed in standard notation: $\delta^{15} \mathrm{~N}$ or $\delta^{13} \mathrm{C}=\left[\left(\mathrm{R}_{\text {sample }} / \mathrm{R}_{\text {standard }}\right)-\right.$ $1] \times 1000$, where $R_{\text {sample }}$ and $R_{\text {standard }}$ are the ratio of ${ }^{15} \mathrm{~N} /{ }^{14} \mathrm{~N}$ or ${ }^{13} \mathrm{C} /{ }^{12} \mathrm{C}$ in the sample and standard (V-PDB for carbon and atmospheric air for nitrogen), respectively. Ammonium sulfate (IAEA-N2) provided by the National standards and Technology Institute (NIST) was used as a standard for nitrogen and NBS22-OIL for carbon. The typical long-term external precision obtained by repeated analyses of primary standards is better than $\pm 0.2 \%$, for both $\delta^{13} \mathrm{C}$ and $\delta^{15} \mathrm{~N}$.

Statistical analysis. Average values of $\delta^{13} \mathrm{C}, \delta^{15} \mathrm{~N}$ and $\mathrm{C}: \mathrm{N}$ were obtained from the duplicate samples analyzed for each individual whale. Relationships between C:N and each stable isotope ratio of jumbo squids and sperm whales were analyzed by using correlation coefficients. Comparisons of the $\delta^{13} \mathrm{C}$ and $\delta^{15} \mathrm{~N}$ of mature male, female and immature male sperm whales were performed using a 1-way analysis of variance (ANOVA). Tukey's post-hoc test was used to identify significant differences among groups. Due to the lack of immature males in 1997 and mature males in 1997 and 1998, as well as the limited number of skin samples from females $(n=1)$ in 1998, we were not able to analyze our data to evaluate isotopic differences on a year-specific basis. However, the isotopic values for 3 categories for which sufficient samples were available (females, immature males and those for which sex could not be established) were compared among the years 1997 to 1999 using a 1-way ANOVA to evaluate the existence of interannual differences in isotopic composition. The relationship between squid mantle length and each stable isotope ratio was analyzed by using the correlation coefficients. Isotopic signatures among large and small jumbo squid were compared using a Student's $t$-test. This data was obtained from a parallel study that evaluated the feeding habits of jumbo squid in the Gulf of California using stomach content as well as stable isotope analysis in muscle and beak tissues (Ruiz-Castro 2002).

\section{RESULTS}

\section{Sperm whales}

The C:N ratios (mean $\pm \mathrm{SD}$ ) for all free-ranging sperm whales - females $(n=15 ; 3.11 \pm 0.11)$, immature males $(\mathrm{n}=10 ; 3.2 \pm 0.10)$, non-differentiated $(\mathrm{n}=10$; $3.3 \pm 0.11)$ and adult males $(n=6 ; 3.6 \pm 0.3)-$ did not show a significant relationship with each stable isotope ratio $\left(\mathrm{r}^{2}=0.4, \mathrm{p}<0.001\right.$ for $\delta^{13} \mathrm{C}$ and $\mathrm{r}^{2}=0.2, \mathrm{p}<0.01$ for $\left.\delta^{15} \mathrm{~N}\right)$. Duplicate sloughed skin samples $(\mathrm{n}=35)$ were consistent (mean $\pm \mathrm{SD}$ ) in both $\delta^{13} \mathrm{C}$ and $\delta^{15} \mathrm{~N}$ values by $0.2 \pm 0.15 \%$, while duplicate biopsy samples $(\mathrm{n}=7)$ showed a consistency (mean \pm SD) of $0.15 \pm 0.05 \%$ for $\delta^{13} \mathrm{C}$ and $0.2 \pm 0.1 \%$ for $\delta^{15} \mathrm{~N}$ values. The $\delta^{15} \mathrm{~N}$ values of 


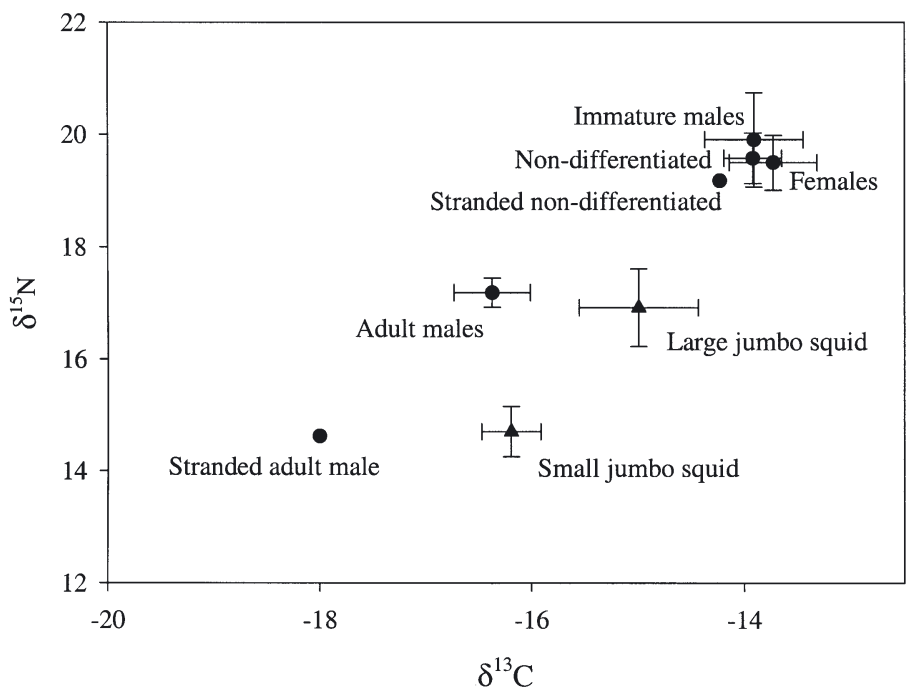

Fig. 2. Physeter macrocephalus and Dosidicus gigas. Stable isotope signatures (\%o; mean $\pm \mathrm{SD}$ ). ๑: sperm whale; $\mathbf{\Delta}$ : jumbo squid

sperm whale skin differed significantly among the sexes and with level of maturation (ANOVA: $F_{2,28}=$ 25.8, p < 0.05) (Fig. 2). Free-ranging adult males had significantly lower $\delta^{15} \mathrm{~N}$ values (by ca. $2.5 \%$ ) than females and immature males (Tukey's: $\mathrm{p}<0.05$ for all comparisons). Carbon isotope values showed more variation among groups, but free-ranging adult males showed significantly lower isotopic values (by $2.5 \%$ o) than females and immature males (ANOVA: $F_{2,28}=$ 92.3, $\mathrm{p}<0.05$; Tukey's: $\mathrm{p}<0.05$ for all comparisons) (Fig. 2). Although immature males showed a slightly higher mean $\delta^{15} \mathrm{~N}$ (by $0.4 \%$ ) than females (Fig. 2), no significant differences were observed in both $\mathrm{C}$ and $\mathrm{N}$ stable isotope values between females and immature males $(p>0.05)$. The stable isotope ratios of the stranded immature individual $\left(\delta^{13} \mathrm{C}=-14.23 \%\right.$ and $\left.\delta^{15} \mathrm{~N}=19.18 \%\right)$ and the adult male $\left(\delta^{13} \mathrm{C}=-18.0 \%\right.$ and $\delta^{15} \mathrm{~N}=14.6 \%$ ) were lower than those for free-ranging sperm whales (Fig. 2). The $\delta^{13} \mathrm{C}$ (ANOVA: $F_{2,32}=0.9, \mathrm{p}$ $>0.05$ ) and $\delta^{15} \mathrm{~N}$ (ANOVA: $F_{2,32}=1.0, \mathrm{p}>0.05$ ) of females, immature males and non-differentiated individuals did not show a significant difference between years, although there was a tendency toward higher $\delta^{15} \mathrm{~N}$ values (ca. $0.4 \%$ ) in the sloughed skin from females, immature males and non-differentiated individuals in 1998 and 1999 compared with the biopsy and sloughed skin collected in 1997 (Table 1).

\section{Jumbo squid}

The mantle length (ML) of small Dosidicus gigas ranged from 20 to $28 \mathrm{~cm}($ mean $=23.8 \pm 2.8 \mathrm{~cm}, \mathrm{n}=8)$, while large squid $\mathrm{ML}$ ranged from 38 to $83.5 \mathrm{~cm}$ (mean $=63.4 \pm 15.1 \mathrm{~cm}, \mathrm{n}=10)$. There was a progressive increase in both $\mathrm{C}$ and $\mathrm{N}$ isotopic values $\left(\mathrm{r}^{2}=0.9\right.$, $\mathrm{p}<0.001$ ) with increasing ML (Table 2). The C:N averages for small $(3.2 \pm 0.04)$ and large $(3.1 \pm 0.03)$ jumbo squid were consistent, inferring that they were biochemically comparable. Both $\delta^{13} \mathrm{C}\left(\mathrm{r}^{2}=0.4, \mathrm{p}<0.01\right)$ and $\delta^{15} \mathrm{~N}\left(\mathrm{r}^{2}=0.3, \mathrm{p} \leq 0.01\right)$ did not show a significant relationship with $\mathrm{C}: \mathrm{N}$ ratios. The carbon and nitrogen isotope ratios of large and small squid showed significant differences ( $t$-test value for $\delta^{13} \mathrm{C}=-5.5$, and $t$-test value for $\left.\delta^{15} \mathrm{~N}=-7.8, \mathrm{p}<0.001\right)$. The large squid were more positive in $\delta^{13} \mathrm{C}$ and $\delta^{15} \mathrm{~N}$ by $1.3 \%$ and $2.2 \%$, respectively (Fig. 2).

\section{Comparison of sperm whale and jumbo squid isotopic composition}

Similar C:N averages for both jumbo squid ( $\mathrm{n}=18$, $3.1 \pm 0.05)$ and sperm whales $(\mathrm{n}=42,3.3 \pm 0.2)$ were obtained. The stable isotope signatures of all female and immature male sperm whales (mean $\pm \mathrm{SD}: \delta^{13} \mathrm{C}=$ $-13.8 \pm 0.4 \%$; $\delta^{15} \mathrm{~N}=19.6 \pm 0.6 \%$ o) were enriched relative to large jumbo squid by $1.1 \%$ and $2.7 \%$ for $\delta^{13} \mathrm{C}$ and $\delta^{15} \mathrm{~N}$, respectively, whereas the trophic enrichment between females and immature males relative to small jumbo squid was $2.4 \%$ for $\delta^{13} \mathrm{C}$ and $5 \%$ for $\delta^{15} \mathrm{~N}$ (Fig. 2). As there was a progressive increase in isotope values with $\mathrm{ML}$, we established ML classes to determine a more precise trophic relationship between sperm whales and jumbo squid (Table 2). The mean $\delta^{13} \mathrm{C}$ enrichment value of female and immature male sperm whales relative to ML classes ( $\mathrm{n}=6$ ) of jumbo squid ranged from 0.4 to $2.4 \%$, whereas the mean enrichment value for $\delta^{15} \mathrm{~N}$ ranged from 1.6 to $5.1 \%$ o (Table 2). Carbon isotope values of mature males were more negative compared with those of both small and large jumbo squid (Fig. 2). Free-ranging mature males were $2.5 \%$ and $0.2 \%$ higher in $\delta^{15} \mathrm{~N}$ relative to small and large jumbo squid, respectively, whereas the stranded mature male was lower in $\delta^{15} \mathrm{~N}$ than small and large squid (Fig. 2).

Table 1. Physeter macrocephalus. Stable isotope values (mean $\pm \mathrm{SD}$, in \%) from skin samples of female, immature male and non-differentiated sperm whales

\begin{tabular}{|rrrrrr|}
\hline Year & $\mathrm{n}$ & $\delta^{13} \mathrm{C}$ & $\mathrm{SD}$ & $\delta^{15} \mathrm{~N}$ & $\mathrm{SD}$ \\
\hline 1997 & 9 & -13.8 & 0.5 & 19.3 & 0.4 \\
1998 & 9 & -13.8 & 0.2 & 19.8 & 0.5 \\
1999 & 17 & -13.9 & 0.4 & 19.8 & 0.7 \\
\hline
\end{tabular}


Table 2. Dosidicus gigas. Stable isotope values (mean $\pm \mathrm{SD}$, in $\%$ ) from different mantle length classes $(n=6$, mean $\pm \mathrm{SD})$, and the corresponding mean stable isotope enrichment of female and immature male sperm whales relative to the mantle length classes of jumbo squid

\begin{tabular}{|lccccc|}
\hline $\begin{array}{l}\text { Mantle length } \\
\text { classes }\end{array}$ & $\mathrm{n}$ & $\delta^{13} \mathrm{C}$ & $\begin{array}{c}\text { Mean } \delta^{13} \mathrm{C} \\
\text { enrichment }\end{array}$ & $\delta^{15} \mathrm{~N}$ & $\begin{array}{c}\text { Mean } \delta^{15} \mathrm{~N} \\
\text { enrichment }\end{array}$ \\
\hline Small & & & & & \\
$22 \pm 1.4$ & 5 & $-16.2 \pm 0.3$ & +2.4 & $14.5 \pm 0.5$ & +5.15 \\
$27 \pm 0.9$ & 3 & $-16.1 \pm 0.2$ & +2.3 & $15.0 \pm 0.2$ & +4.65 \\
Large & & & & & \\
$40 \pm 1.8$ & 2 & $-15.6 \pm 0.2$ & +1.8 & $16.1 \pm 0.5$ & +3.55 \\
57 & 1 & -15.1 & +1.3 & 17.2 & +2.45 \\
$66 \pm 1.9$ & 5 & $-14.8 \pm 0.5$ & +1.0 & $16.8 \pm 0.4$ & +2.85 \\
$82 \pm 2.1$ & 2 & $-14.2 \pm 0.1$ & +0.4 & $17.9 \pm 0.4$ & +1.65 \\
\hline
\end{tabular}

\section{DISCUSSION}

Our study supports the use of stable isotope analysis of sloughed skin samples from sperm whales as a complementary non-invasive method with which to make inferences about the diet of free-ranging individuals. The isotopic analysis of metabolically inactive tissue such as skin is likely to reflect the diet of individuals only during the period of growth (Hobson \& Clark 1992a, Hobson et al. 1996). There is no data available with which to estimate the skin growth of sperm whales, but the epidermal turnover rate of other odontocetes could be a point of reference. In beluga Delphinapterus leucas (St. Aubin et al. 1990) and the bottlenose dolphin Tursiops truncatus (Hicks et al. 1985), the suggested total time required for cell migration from the basal lamina to the outermost surface is 70 to $75 \mathrm{~d}$. The skin of sperm whales is thicker than that of other odontocetes (Rice 1989). Although we cannot assume that these rates are directly applicable to sperm whales, these estimates can improve the interpretation of isotopic data for this species. We suggest that the epidermal turnover time for sperm whale skin may be at least $75 \mathrm{~d}$ and probably longer due to their thicker skin when compared with smaller odontocetes.

The similarity between the stable isotope signatures of female and immature male sperm whales suggests that they assimilated a diet of equivalent composition (Fig. 2). These results are in agreement with previous stomach content studies of sperm whales caught in South Africa (Clarke 1980) and in the southern Pacific (Clarke et al. 1988). In these areas, females and immature males ingested a similar variety and size of prey. In our study, both the $\delta^{13} \mathrm{C}$ and $\delta^{15} \mathrm{~N}$ values of predators (females and immature male sperm whales) showed a positive isotopic discrimination of $1.0 \%$ and $2.7 \%$, respectively, relative to the potential prey-large jumbo squid (Fig. 2). These values are in agreement with the estimated average trophic level enrichment for animal tissues relative to their diet. The stable carbon isotope ratio shows an isotopic discrimination of about 0.8 to $1.0 \%$ per trophic level (DeNiro \& Epstein 1978, Fry \& Sherr 1984), contrasting with 2.6 to $3.4 \%$ for the $\delta^{15} \mathrm{~N}$ discrimination between predator and prey (Minagawa \& Wada 1984, Wada et al. 1987, Fry 1988) and by an average of ca. $3.3 \%$ when consumers are raised on a high-protein diet (McCutchan et al. 2003). Because the difference in the isotopic composition of females and immature males relative to small Dosidicus gigas (Fig. 2, Table 2) falls outside the expected overall trophic level enrichments for both $\delta^{13} \mathrm{C}$ and $\delta^{15} \mathrm{~N}$, our results suggest that small squid were probably not an important part of the sperm whale diet compared with large jumbo squid that appeared to be their principal prey item. However, if we increase the range of values from 2.5 to $5 \%$ for $\delta^{15} \mathrm{~N}$ trophic shift enrichment, then female and immature male sperm whales may have consumed a broader range of jumbo squid sizes (from $27 \pm 0.9 \mathrm{~cm} \mathrm{ML}$ to 66 $\pm 0.9 \mathrm{~cm} \mathrm{ML})($ Table 2). Although sampling other potential dietary items of sperm whales in the Gulf of California was desirable, the results of this study fulfill the initial objective of evaluating the trophic relationship between sperm whales and jumbo squid.

The observed differences in $\delta^{13} \mathrm{C}$ values (ca. $1 \%$ ) between small and large jumbo squid were associated with distinct feeding locations rather than seasonal variation, while the size-related change in $\delta^{15} \mathrm{~N}$ reflected an increase in trophic position. The former was revealed from a parallel study that showed a similar progressive increase of $\delta^{13} \mathrm{C}$ and $\delta^{15} \mathrm{~N}$ values in muscle and beak tissues with a corresponding sizerelated increase in jumbo squid (Ruiz-Castro 2002).

The predator-prey relationship between sperm whales and jumbo squid has been shown previously in other oceanic areas. In the SE Pacific, jumbo squid occurred in $99 \%$ of the stomachs of approximately 2000 sperm whales hunted between 1959 and 1962 (Clarke et al. 1988). In the Gulf of California, the only direct evidence that indicates jumbo squid as prey of sperm whales comes from squid beaks of Dosidicus gigas (from 48 to $78 \mathrm{~cm} \mathrm{ML}$ ) and Ancistrocheirus lessueurii collected in the stomach of an immature male sperm whale stranded in the southwestern part of the Gulf (Ruiz-Castro 2002, R.I. Ruiz-Castro, U. Markaida unpubl.). The stable isotope ratios in muscle $\left(\delta^{13} \mathrm{C}=-15.5 \% \pm 1.0\right.$ and $\delta^{15} \mathrm{~N}=16.3 \%$ o \pm 0.6$)$ were estimated by using jumbo squid beaks collected from the stranded sperm whale (Ruiz-Castro 2002). Previous values of both $\mathrm{ML}$ and stable isotope ratios are more 
similar to those of large jumbo squid from the present study (Table 2).

Analysis of stomach contents from sperm whales caught in the SE Pacific showed that sperm whales fed on larger jumbo squid than those caught by the squid fisheries (Clarke et al. 1988, Clarke \& Paliza 2000). The size distribution of the squid caught by the fishery off Peru had a primary mode at $35 \mathrm{~cm}$ and a secondary mode at $75 \mathrm{~cm} \mathrm{ML}$, whereas the jumbo squid collected from sperm whale stomachs showed a single mode at 75 to $85 \mathrm{~cm}$ (Clarke \& Paliza 2000). In the Gulf of California from 1995 to 1996, the sizes of jumbo squid with the highest catch rates were estimated at 29-33, 53-57, and 65-71 cm ML (Morales-Bojorquez \& Martínez-Aguilar 2001). Considering these catch rates, and assuming a trophic enrichment of $1 \%$ for $\delta^{13} \mathrm{C}$ and $3 \%$ for $\delta^{15} \mathrm{~N}$, it appears that females and juvenile sperm whales tended to feed on Dosidicus gigas of $66 \pm$ $1.9 \mathrm{~cm}$ ML (Table 2). Therefore, a possible overlap in resource competition is suggested between sperm whales and the commercial fishery of squid in the Gulf of California.

The low variation in both $\delta^{13} \mathrm{C}$ and $\delta^{15} \mathrm{~N}$ values between female and juvenile sperm whales sampled between 1997 and 1999 suggests that they fed on dietary items from the same regional food web (indicated by the similar $\delta^{13} \mathrm{C}$ values) and at a similar trophic position (indicated by the $\delta^{15} \mathrm{~N}$ values) during those years (Table 1). These results suggest that female and immature sperm whales remained in the Gulf of California, and they were able to continue feeding on large Dosidicus gigas in 1998 despite the El Niño Southern Oscillation (ENSO) conditions that prevailed in that year. In the Galapagos, the foraging success of sperm whales, estimated by defecation rates, had a strong negative correlation with ENSO conditions (Smith \& Whitehead 1993, Whitehead 1996). In areas and years of low food abundance, migration is suggested to be the principal strategy when sperm whales face a decreased food supply (Whitehead 1996). In the Gulf of California, the relative abundance of sperm whales remained similar between 1998 and 1999, while the distribution pattern and foraging effort of sperm whales changed significantly in those years (Jaquet \& Gendron 2002, Jaquet et al. 2003). In addition, dramatic changes in the abundance and distribution of jumbo squid were observed during 1998. Apparently, the jumbo squid migrated southward toward the mouth of the Gulf of California, where a fishery was established in uncommon areas (MoralesBojórquez et al. 2001). In the same year, sperm whales apparently increased their foraging effort, for example, diving for longer periods than in 1999 (Jaquet et al. 2003), perhaps because the jumbo squid were distributed in deeper waters.
The stable isotope ratios of adult male sperm whales were significantly different and unexpectedly lower than those of females and immature males (Fig. 2). In addition, mature males did not appear to show a trophic relationship with Dosidicus gigas. The isotopic differences (adult males versus females and immature males) suggest differences in their diet composition. This result is in agreement with other studies based on stomach content analysis. In British Columbia, Canada, the diet of sperm whales differed significantly between sexes: females fed more frequently on North Pacific giant squid (Moroteuthis robusta), whereas males fed on rockfish (Sebastes spp.) and dogfish (Squalus acanthias) (Flinn et al. 2002). Nevertheless, we expected to find higher stable isotope signatures for adult males compared with those of females and juveniles, as their prey is generally larger. For example, stomach content remains have revealed that large male sperm whales ingest larger sizes of similar prey than females and juveniles (Clarke 1980, Clarke et al. 1988, Best 1999).

Few other stable isotope signatures for sperm whale tissues have been reported. In the North Atlantic, the stable isotope ratios measured from the muscle of a sperm whale were $-22.8 \%$ for $\delta^{13} \mathrm{C}$ and $11.1 \%$ for $\delta^{15} \mathrm{~N}$ (Ostrom et al. 1993). These values as well as the isotopic signature in liver $\left(\delta^{13} \mathrm{C}=-18.4 \% \pm 0.3\right.$ and $\delta^{15} \mathrm{~N}=$ $13.2 \% \pm 0.6)$ and muscle $\left(\delta^{13} \mathrm{C}=-19.0 \% \pm 0.9\right.$ and $\left.\delta^{15} \mathrm{~N}=14.6 \% \pm 0.6\right)$ of stranded sperm whales in the North Sea (Das et al. 2003) are lower than those of adult males in the Gulf of California. Additionally, the stable isotope ratios from a single tooth of a sperm whale, in which sequential dentin layers were analysed, showed that both $\delta^{13} \mathrm{C}(-12.1$ to $-13.8 \%)$ and $\delta^{15} \mathrm{~N}(18.1$ to $16.1 \%$ ) tend to become lower with age (Walker \& Macko 1999). Our results are consistent with this finding because the sloughed skin samples from immature males were higher in both $\delta^{13} \mathrm{C}$ and $\delta^{15} \mathrm{~N}$ composition compared with those from mature males (Fig. 2). Thus, it seems that the decreasing isotopic values from male sperm whales could be a result of agerelated change in their feeding grounds.

A remarkable characteristic of sperm whales is their strong sexual segregation in both distribution (Rice 1989) and social organization (Whitehead et al. 1991). In general, mature males inhabit high latitudes, almost to the edge of the pack ice (Rice 1989), and are believed to migrate seasonally to tropical waters (Best 1979). In contrast, females and their offspring are found mostly in tropical and subtropical waters $\left(50^{\circ} \mathrm{N}\right.$ to $40^{\circ} \mathrm{S}$, Pacific Ocean) (Rice 1989) and range over distances of approximately $1000 \mathrm{~km}$ (Best 1979, Dufault \& Whitehead 1995). Globally, sperm whales have a higher fish intake in waters of high latitudes than in waters of low latitudes (Kawakami 1980, Rice 1989). In 
the NE Pacific, sperm whales fed predominately on fish rather than squid along the Gulf of Alaska and in the eastern Bering Sea (Okutani \& Nemoto 1964). Therefore, if mature males were in a high-latitude feeding ground before entering the Gulf of California, they would have a different stable isotopic signature in their tissues as a result of their geographic diet composition. Differences in the turnover rates of particular tissues determine the length of time that animals moving between isotopically distinct food webs can retain information from previous feeding locations (Hobson \& Clark 1992a). At high latitudes, marine phytoplankton show lower $\delta^{13} \mathrm{C}$ values than at lower latitudes (Rau et al. 1982). Similar $\delta^{13} \mathrm{C}$ latitude-related isotopic variation is reflected in consumers like squid (Takai et al. 2000) and nearshore- and offshore-foraging pinnipeds (Burton \& Koch 1999), while the $\delta^{15} \mathrm{~N}$ in squid tissues reflects the local nitrogen metabolism rather than a latitudinal isotopic gradient (Takai et al. 2000). Therefore, if a mature male migrates in a direct route from the Gulf of Alaska (55 $34^{\prime} \mathrm{N}$ and $140^{\circ} 13^{\prime} \mathrm{W}$ ), around the Baja California Peninsula of Mexico, and finally to the central part of the Gulf of California $\left(28^{\circ} 30^{\prime} \mathrm{N}\right.$ and $\left.112^{\circ} 02^{\prime} \mathrm{W}\right)$, this example of long-distance migration (ca. $6142 \mathrm{~km}$ ) would take approximately $68 \mathrm{~d}$ (calculation based on a travelled distance of $90 \mathrm{~km} \mathrm{~d}^{-1}$ in a straight line movement when females and immature sperm whales face low feeding success; Whitehead 1996, Jaquet \& Whitehead 1999). This migrating time is shorter than the epidermal turnover time estimated for smaller odontocetes, such as beluga and bottlenose dolphins (75 d). Thus, it might support the idea that the sloughed skin of mature males retained the stable isotopic signatures from a high-latitude feeding ground.

Another aspect that may imply variations in the stable isotope ratios in sperm whale tissues could be the fasting condition experienced during a long-distance migration. The storage of energy as a fat layer enables whales to cope with the energetic cost of migration and drastic changes in food supply (Lockyer 1987). As mature male sperm whales migrate from cold waters to tropical breeding grounds, they may suffer decreased feeding opportunities, which may require them to fast for extended periods and thus depend on their accumulated lipids. During fasting or nutritional stress, a depletion in ${ }^{13} \mathrm{C}$ and ${ }^{15} \mathrm{~N}$ may occur in tissues if adipose reserves are used preferentially as an energy source in animals with excess fat deposits (i. e. polar bears, Polischuk et al. 2001), or an increase in ${ }^{15} \mathrm{~N}$ may result when catabolism of the body's proteins are the energy source (Hobson \& Clark 1992b, Polischuk et al. 2001). Therefore, the isotopic signature in tissues of whales with a large-scale migration might vary from the initial high-latitude feeding ground as a result of fasting.
In addition, the stable isotope signatures were lower in both the stranded adult male and the undifferentiated individuals compared with those for the freeranging adult male and non-differentiated sperm whales, respectively (Fig. 2). Emaciation could be an indicator of sickness, starvation or any other unhealthy condition, which is commonly observed in stranded animals. Because stranded animals have an unknown cause of death, their stable isotope signature could reflect an abnormal diet.

\section{CONCLUSIONS}

Sperm whales were extensively hunted worldwide during the last 2 centuries, yet only a few studies have evaluated the differences in diet composition as a function of sex and level of maturity during the same season and within the same oceanic area (e.g. Clarke 1980, Clarke et al. 1988, Best 1999, Flinn et al. 2002). This study provided a new non-invasive methodstable isotope ratios from sloughed skin-to infer the relative trophic position and prey relationships of free-ranging sperm whales. The method is useful for evaluating temporal and spatial variations in the diets of sperm whales, and could be applicable for other cetaceans. Further investigation of the seasonal and inter-annual variation of sperm whale skin as a function of sex and level of maturity will provide a better understanding of the feeding ecology of this species. Future determination of the stable isotope fractionation from the skin of cetaceans and muscle tissue of prey items such as fish and squid will provide a more precise indication of predator-prey relationships and ultimately enable us to investigate trophic structure and relationships in the pelagic realm.

Acknowledgements. Special thanks are extended to U. Markaida from the Centro de Investigación Científica y de Educación Superior de Ensenada (CICESE) for providing jumbo squid samples from 1996 to 1997, and to L. RojasBracho from the CRIP and the Instituto Nacional de Ecologia, Mexico, for providing skin samples of sperm whales in 1997. We are very grateful to N. Jaquet who supported the collection of data and skin samples of sperm whales in the summer of 1998 to 1999, along with John Botke who allowed us the use of his sailing vessel. We are also grateful to J. Hyde for helping with sex determination. We thank J. Villaescusa and P. Castro for laboratory support in the stable isotope analysis. Special thanks are extended to S. Z. Herzka (CICESE, Mexico) for her important and helpful comments on the manuscript, and to J. J. Cooley for helping with the English edition. We thank anonymous reviewers for their comments. This research project was funded under the Comisión Nacional para el conocimiento y uso de la Biodiversidad (Mexico), under the scientific permit no. 040598-213-0 (1998) and no. DOO02.2081 (1999) from the Secretaria de Medio Ambiente Recursos Naturales y Pesca, Mexico. 


\section{LITERATURE CITED}

Amos W, Hoelzel A R (1991) Long-term preservation of whale skin for DNA analysis. Rep Int Whaling Comm Spec Issue 13:99-103

Bérubé M, Palsboll P (1996) Identification of sex in cetaceans by multiplexing with three ZFX and ZFY specific primers. Mol Ecol 5:283-287

Berzin AA (1971) Kashalot: izdatel'stvo 'pishchevaya promyshlennost' Moskwa. In: Yablokov AV (ed) The sperm whale. Israel Program for Scientific Translations, Jerusalem, p 189-209

Best PB (1979) Social organization in sperm whales, Physeter macrocephalus. In: Winn HE, Olla BL (eds) Behavior of marine animals. Plenum Press, New York, p 227-289

Best PB (1999) Food and feeding of sperm whales Physeter macrocephalus off the west coast of South Africa. S Afr J Mar Sci 21:393-413

Bligh ES, Dyer WJ (1959) A rapid method of total lipid extraction and purification. Can J Biochem Physiol 37:911-917

Burton RK, Koch PL (1999) Isotopic tracking of foraging and long-distance migration in northeastern Pacific pinnipeds. Oecologia 119:578-585

Clarke MR (1980) Cephalopoda in the diet of sperm whales of the southern hemisphere and their bearing on sperm whale biology. Discovery Rep 37:1-324

Clarke MR (1983) Cephalopod biomass-estimation from predation. In: Boyle PR (ed) Cephalopod life cycles. Academic Press, London, p 221-237

Clarke MR (1985) Cephalopods in the diet of cetaceans and seals. Rapp Comm Int Mer Médit 29:211-218

Clarke MR (1986) Cephalopods in the diet of odontocetes. In Bryden MM, Harrison R (eds) Research on dolphins. Clarendon Press, Oxford, p 281-321

Clarke R, Paliza O (2000) The Humboldt Current squid Dosidicus gigas (Orbigny, 1835). Rev Biol Mar Oceanogr 35:1-39

Clarke R, Paliza O (2001) The food of sperm whales in the southeast Pacific. Mar Mamm Sci 17:427-429

Clarke R, Paliza O, Aguayo A (1988) Sperm whales of the Southeast Pacific. Part IV. Fatness, food and feeding. Invest Cetacea 21:54-195

Das K, Lepoint G, Leroy Y, Bouquegneau JM (2003) Marine mammals from the southern North Sea: feeding ecology data from $\delta^{13} \mathrm{C}$ and $\delta^{15} \mathrm{~N}$ measurements. Mar Ecol Prog Ser 263:287-298

DeNiro MJ, Epstein S (1977) Mechanisms of carbon isotope fractionation associated with lipid synthesis. Science 197: 261-263

DeNiro MJ, Epstein S (1978) Influence of diet on the distribution of carbon isotopes in animals. Geochim Cosmochim Acta 42:495-506

DeNiro MJ, Epstein S (1981) Influence of diet on the distribution of nitrogen in animals. Geochim Cosmochim Acta 45: $341-351$

Dufault S, Whitehead H (1995) The geographic stock structure of female and immature sperm whales in the South Pacific. Rep Int Whaling Comm 45:401-405

Flinn R, Trites AW, Gregr EJ, Perry RI (2002) Diets of fin, sei, and sperm whales in British Columbia: an analysis of commercial whaling records, 1963-1967. Mar Mamm Sci 18:663-679

Fry B (1988) Food web structure on Georges Bank from stable C, N and S isotopic composition. Limnol Oceanogr 33: $1182-1190$

Fry B, Sherr EB (1984) ${ }^{13} \mathrm{C}$ measurements as indicators of carbon flow in marine and freshwater ecosystems. Contrib Mar Sci 27:13-47
Gendron D, Aguíñiga S, Carriquiry JD (2001) $\delta^{15} \mathrm{~N}$ and $\delta^{13} \mathrm{C}$ in skin biopsy samples: a note on their applicability for examining the relative trophic level in three rorqual species. J Cetacean Res Manag 3:41-44

Hicks BD, St. Aubin DJ, Geraci JR, Brown WR (1985) Epidermal growth in the bottlenose dolphin, Tursiops truncatus. J Invest Dermatol 85:60-63

Hobson KA, Clark RG (1992a) Assessing avian diets using stable isotopes. I. Turnover of ${ }^{13} \mathrm{C}$ in tissues. Condor 94: 181-188

Hobson KA, Clark RG (1992b) Assessing avian diets using stable isotopes. II. Factors influencing diet-tissue fractionation. Condor 94:189-197

Hobson KA, Welch HE (1992) Determination of trophic relationships within a high Arctic marine food web using $\delta^{13} \mathrm{C}$ and $\delta^{15} \mathrm{~N}$ analysis. Mar Ecol Prog Ser 84:9-18

Hobson KA, Piatt JF, Pitocchelli J (1994) Using stable isotopes to determine seabird trophic relationships. J Anim Ecol 63: 786-798

Hobson KA, Schell DM, Renouf D, Noseworthy E (1996) Stable carbon and nitrogen isotopic fractionation between diet and tissues of captive seals: implications for dietary reconstructions involving marine mammals. J Fish Aquat Sci 53:528-533

Hooker SK, Iverson SJ, Ostrom P, Smith SC (2001) Diet of northern bottlenose whales inferred from fatty-acid and stable-isotope analyses of biopsy samples. Can J Zool 79: 1442-1454

Jaquet N, Gendron D (2002) Distribution and relative abundance of sperm whales in relation to key environmental features, squid landings and the distribution of other cetacean species in the Gulf of California, Mexico. Mar Biol 141:591-601

Jaquet N, Whitehead H (1999) Movements, distribution and feeding success of sperm whales in the Pacific Ocean, over scales of days and tens of kilometres. Aquat Mamm 25: $1-13$

Jaquet N, Gendron D, Coakes A (2003) Sperm whales in the Gulf of California: residency, movements, behaviour, and the possible influence of variation in food supply. Mar Mamm Sci 19:545-562

Kawakami T (1980) A review of sperm whale food. Sci Rep Whales Res Inst 32:199-218

Lockyer C (1987) Evaluation of the role of fat reserves in relation to the ecology of North Atlantic fin and sei whales. In: Huntley AC, Costa DP, Worthy GAJ, Castellini MA (eds) Marine mammals energetics. Society for Marine Mammalogy, Lawrence, KS, p 183-203

McCutchan Jr JH, Lewis WM, Kendall C, McGrath CC (2003) Variation in trophic shift for stable isotope ratios of carbon, nitrogen, and sulfur. Oikos 102:378-390

Minagawa M, Wada E (1984) Stepwise enrichment of ${ }^{15} \mathrm{~N}$ along food chains: further evidence and the relation between $\delta^{15} \mathrm{~N}$ and animal age. Geochim Cosmochim Acta 48:1135-1140

Morales-Bojórquez E, Martínez-Aguilar S (2001) Estimations of catchability-at-length for the jumbo squid (Dosidicus gigas) fishery in the Gulf of California, Mexico. Calif Coop Ocean Fish Investig Rep 42:167-171

Morales-Bojórquez E, Cisneros-Mata MA, Neváres-Martínez MO, Hernández-Herrera A (2001) Review of stock assessment and fishery research for Dosidicus gigas in the Gulf of California, Mexico. Fish Res 54:83-94

Nigmatullin CM, Nesis KN, Arkhipkin AI (2001) Biology of the jumbo squid Dosidicus gigas (Cephalopoda: Ommastrephidae). Fish Res 54:9-19

Okutani T, Nemoto T (1964) Squids as the food of sperm 
whales in the Bering Sea and Alaskan Gulf. Sci Rep Whales Res Inst 18:111-122

Ostrom PH, Lien J, Macko SA (1993) Evaluation of the diet of Sowerby's beaked whale, Mesoplodon bidens, based on isotopic comparisons among Northwestern Atlantic cetaceans. Can J Zool 71:858-861

Pascoe PL, Michkiewicz MC, Castello HP (1990) Cephalopod remains from the stomach of a sperm whale stranded off Patagonia. Mar Biol 104:1-4

Polischuk SC, Hobson KA, Ramsay MA (2001) Use of stablecarbon and nitrogen isotopes to assess weaning and fasting in female polar bears and their cubs. Can J Zool 79:499-511

Rau J, Sweeney RH, Kaplan IR (1982) Plankton ${ }^{13} \mathrm{C}^{12} \mathrm{C}$ ratio changes with latitude: differences between northern and southern ocean. Deep-Sea Res 29:1035-1039

Rau GH, Mearns AJ, Young DR, Olson RJ, Schafer HA, Kaplan IR (1983) ${ }^{13} \mathrm{C} /{ }^{12} \mathrm{C}$ correlates with trophic level in pelagic food webs. Ecology 64:1314-1318

Rau GH, Ainley DG, Bengtson JL, Torres JJ, Hopkins TL (1992) ${ }^{15} \mathrm{~N} /{ }^{14} \mathrm{~N}$ and ${ }^{13} \mathrm{C} /{ }^{12} \mathrm{C}$ in Weddell Sea birds, seals and fish: implications for diet and trophic structure. Mar Ecol Prog Ser 84:1-8

Rice DW (1989) Sperm whale, Physeter macrocephalus Linnaeus, 1758. In: Ridgway SH, Harrison SR (eds) Handbook of marine mammals, Vol 4. Academic Press, London, p 177-233

Richard KR, McCarrey SW, Wright JM (1994) DNA sequence from the SRY gene of the sperm whale (Physeter macrocephalus) for use in molecular sexing. Can J Zool 72: 873-877

Rosenberg A, Mesnick SL (2001) The cetacean ZFX and ZFY genes: interfamilial characterization of a novel region facilitates gender determination. SWFSC Admin Rep, NOAA Fisheries, La Jolla, CA, LJ-01-01

Ruiz-Castro RI (2002) Relación trófrica entre el cachalote (Physeter macrocephalus) y el calamar gigante (Dosidicus gigas) en el Golfo de California mediante el análisis de isótopos estables de carbono y nitrógeno. MS thesis, CICIMAR-IPN, La Paz

Smith S, Whitehead H (1993) Variation in the feeding success and behaviour of Galápagos sperm whales (Physeter macrocephalus) as they relate to oceanographic condi-

Editorial responsibility: Otto Kinne (Editor),

Oldendorf/Luhe, Germany tions. Can J Zool 71:1991-1996

Smith S, Whitehead H (2000) The diet of Galapagos sperm whales Physeter macrocephalus as indicated by fecal sample analysis. Mar Mamm Sci 16:315-325

Smith S, Whitehead H (2001) Reply to R. Clarke and Paliza's comment: 'The food of sperm whales in the Southeast Pacific'. Mar Mamm Sci 17:430-431

St. Aubin DJ, Smith TG, Geraci JR (1990) Seasonal epidermal molt in beluga, Delphinapterus leucas. Can J Zool 68: 359-367

Takai N, Onaka S, Ikeda Y, Yatsu A, Kidokoro H, Sakamoto W (2000) Geographical variations in carbon and nitrogen stable isotope ratios in squid. J Mar Biol Assoc UK 80: $675-684$

Tieszen LL, Boutton TW, Tesdahl KG, Slade NA (1983) Fractionation and turnover of stable carbon isotopes in animal tissues: implication for $\delta^{13} \mathrm{C}$ analysis of diet. Oecología 57: $32-37$

Todd SK, Ostrom P, Lien J, Abrajano J (1997) Use of biopsy samples of humpback whale (Megaptera novaengliae) skin for stable isotope $\left(\delta^{13} \mathrm{C}\right)$ determination. J Northwest Atl Fish Sci 22:71-76

Vidal O, Findley LT, Leatherwood S (1993) Annotaded checklist of the marine mammals of the Gulf of California. Proc S Diego Soc Nat Hist 28:1-11

Wada E, Terazaki M, Kabaya Y, Nemoto T (1987) ${ }^{15} \mathrm{~N}$ and ${ }^{13} \mathrm{C}$ abundances in the Antartic Ocean with emphasis on the biogeochemical structure of the food web. Deep-Sea Res 34:829-841

Walker JL, Macko SA (1999) Dietary studies of marine mammals using stable carbon and nitrogen isotopic ratio of teeth. Mar Mamm Sci 15:314-334

Whitehead H (1996) Variation in the feeding success of sperm whales: temporal scale, spatial scale and relationship to migrations. J Anim Ecol 65:429-438

Whitehead H, Arnbom T (1987) Social organization of sperm whales off the Galapagos Islands, February-April 1985. Can J Zool 65:913-919

Whitehead H, Waters S, Lyrholm T (1991) Social organization of female sperm whales and their offspring: constant companions and casual acquaintances. Behav Ecol Sociobiol 29:285-289

Submitted: July 8, 2003; Accepted: May 6, 2004

Proofs received from author(s): August 3, 2004 